Jurnal Keperawatan Silampari

Volume 4, Nomor 2, Juni 2021

e-ISSN: 2581-1975

p-ISSN: 2597-7482

DOI: https://doi.org/10.31539/jks.v4i2.1668

\title{
HUBUNGAN ANTARA KARAKTERISTIK, PENGETAHUAN DENGAN KEJADIAN KANKER SERVIKS
}

\author{
Magdalena Eijer Ge'e ${ }^{1}$, Adelina Lebuan ${ }^{2}$, Justina Purwarini ${ }^{3}$ \\ Sekolah Tinggi Ilmu Kesehatan Sint Carolus ${ }^{1,2,3}$ \\ epriskilagee@gmail.com ${ }^{1}$
}

\begin{abstract}
ABSTRAK
Penelitian ini bertujuan untuk mengetahui hubungan antara karakteristik, pengetahuan dengan kejadian kanker serviks di rumah sakit. Desain penelitian adalah deskriptif korelatif dengan pendekatan cross sectional. Hasil penelitian menunjukkan bahwa tidak ada hubungan usia dengan kejadian kanker serviks di rumah sakit dengan p-value 0,099 $(\mathrm{p}>0,05)$, pada variabel pendidikan ( $\mathrm{p}$-value $=0,003)$, pekerjaan $(\mathrm{p}$-value $=0,030)$, paritas $(\mathrm{p}$-value $=0,013)$, pengetahuan $(\mathrm{p}$-value $=0,007)$. Simpulan, ada hubungan bermakna antara pendidikan, pekerjaan, paritas dan pengetahuan responden dengan kejadian kanker serviks di rumah sakit.
\end{abstract}

Kata Kunci : Kesehatan Reproduksi, Pengetahuan, Promosi Kesehatan

\section{ABSTRACT}

This study aims to determine the relationship between characteristics, knowledge, and the incidence of cervical cancer in the hospital. The research design was correlative descriptive with the cross-sectional approach. The results showed that there was no relationship between age and the incidence of service cancer in the hospital with a pvalue of $0.099(p>0.05)$, on the education variable ( $p$-value $=0.003)$, occupation $(p$ value $=0.030)$, parity. $(p$-value $=0.013)$, knowledge $(p$-value $=0.007)$. In conclusion, there is a significant relationship between education, occupation, parity, and knowledge of respondents with the incidence of cervical cancer in the hospital.

Keywords: Reproductive Health, Knowledge, Health Promotion

\section{PENDAHULUAN}

Kanker serviks adalah penyakit yang ditandai dengan pertumbuhan sel yang tidak terkontrol dan penyebaran sel yang abnormal (Herlana et al., 2017). Kanker leher rahim atau lebih dikenal dengan kanker serviks merupakan penyebab kematian akibat kanker yang terbesar bagi wanita di negara-negara berkembang. Secara global terdapat 600.000 kasus baru dan 300.000 kematian setiap tahunnya, yang hampir $80 \%$ terjadi di negara berkembang. Fakta-fakta tersebut membuat kanker leher rahim menempati posisi kedua kanker terbanyak pada perempuan di dunia dan menempati urutan pertama di negara berkembang (Nurlelawati et al., 2018).

Kanker serviks termasuk masalah kesehatan yang sangat serius dan menjadi perhatian dunia. Setiap tahun, lebih dari 300.000 wanita meninggal dunia. Lebih dari setengah juta wanita di diagnosis dan tiap menit seorang wanita di diagnosis. Kanker ini menempati urutan keempat yang paling banyak diderita wanita di dunia. Diperkirakan 
570.000 kasus baru pada tahun 2018, mewakili 6,6 \% dari semua kanker yang dialami wanita (WHO, 2019).

Berdasarkan data Globocan, saat ini beban penyakit kanker di dunia meningkat, yaitu terdapat 18,1 juta kasus baru dengan angka kematian sebesar 9,6 juta kematian di tahun 2018, dimana 1 dari 5 laki-laki dan 1 dari 6 perempuan di dunia mengalami kejadian kanker, serta 1 dari 8 laki-laki dan 1 dari 11 perempuan meninggal karena kanker. Insiden dan mortalitas kanker di Indonesia terus meningkat, salah satu kanker pada wanita yang sering terjadi adalah kanker serviks, sekitar 0,8\% per 1.000 penduduk (Kemkes RI, 2019).

Banyak faktor yang mempengaruhi seorang wanita terkena kanker serviks, diantaranya usia aktivitas seksual pertama kali, usia saat ini, pendidikan serta gaya hidup (Puspitasari et al., 2018; Nurlelawati et al., 2018). Pada beberapa penelitian kasus ini tidak memiliki hubungan yang signifikan dengan pekerjaan serta paritas ibu (Nurlelawati et al., 2018; Puspitasari et al., 2018; Wasiah, 2019).

Berbeda dengan pendapat Trifitriana., et al (2020) yang mengatakan bahwa paritas merupakan salah satu aktivitas seksual yang menjadi faktor risiko terjadinya kanker seviks. Seorang ibu yang sering melahirkan dapat menyebabkan trauma pada jalan lahir dan dapat menimbulkan sel-sel abnormal pada mulut rahim yang dapat berkembang menjadi keganasan. Penelitian yang dilakukan oleh Kusmiyati., et al (2019) juga mengatakan bahwa lamanya durasi pemakaian alat kontrasepsi hormonal pada akseptor KB memiliki pengaruh terhadap angka kejadian kanker serviks. Kejadian kanker serviks akan meningkat empat kali lebih besar pada akseptor $\mathrm{KB}$ yang menggunakan alat kontrasepsi hormonal dengan durasi waktu lebih dari lima tahun.

Kementrian kesehatan RI telah mengembangkan program pencegahan kanker serviks sejak tiga belas tahun yang lalu. Pada tahun 2014 diharapkan kabupaten dan kota di Indonesia dapat melakukan deteksi dini terhadap kanker serviks dengan sasaran $80 \%$. Menjalani tes kanker atau pra-kanker dianjurkan bagi semua perempuan berusia 30-50 tahun khususnya yang sudah melakukan hubungan seksual. Wanita yang termasuk dalam kelompok resiko tinggi yaitu mereka yang pertama kali melakukan hubungan seksual di usia muda ( $<20$ tahun), memiliki banyak pasangan seksual, pernah mengalami IMS atau HIV/AIDS, riwayat keluarga yang terkena kanker serviks dan merokok (Surbakti, 2020).

Masih tingginya angka kejadian kanker serviks diperlukan adanya sosialisasi ataupun penyuluhan bagi masyarakat untuk melakukan deteksi dini terhadap kemungkinan terjadinya kanker serviks. Penelitian tentang hubungan antara karakteristik responden terhadap kejadian kanker servik sudah pernah dilakukan, namun pada penelitian ini berfokus pada hubungan antara karakteristik responden seperti pendidikan, pekerjaan, paritas, pengetahuan dan usia responden.

\section{METODE PENELITIAN \\ Rancangan Penelitian}

Penelitian ini merupakan penelitian kuantitatif menggunakan deskriptif korelatif dengan pendekatan cross sectional.

\section{Variabel Penelitian}

Penelitian menggunakan dua variabel yaitu variabel independen dan variabel dependent. Variabel independen yang diteliti yaitu karakteristik yang meliputi usia, 
pendidikan, pekerjaan, paritas serta pengetahuan partisipan, sedangkan variabel dependent adalah kajadian kanker serviks.

Populasi dalam penelitian ini adalah semua pasien yang kontrol di poli ginekologi kebidanan rumah sakit dalam 3 bulan terakhir yang berjumlah 226 orang pasien. Sampel dalam penelitian ini dihitung menggunakan table kretjie, dimana dengan jumlah populasi 226 dengan taraf kesalahan 5\% maka sampel yang diperoleh 144 responden. Adapun kriteria inklusi yang ditetapkan yaitu pasien yang datang berobat ke poliklinik ginekologi kebidanan rawat jalan, bersedia menjadi responden penelitian dan mampu membaca, menulis dan berkomunikasi dengan bahasa Indonesia.

Peneliti mengumpulkan data dengan cara menyebarkan kuesioner di tempat penelitian, menggunakan teknik purposive sampling yaitu dengan cara sampel diambil bertujuan pada anggota yang dianggap memenuhi kriteria inklusi.

Penelitian ini menggunakan data primer dengan kuesioner yang didesain oleh peneliti dan telah diuji validitas serta relilabilitasnya. Alpha cronbach kuesioner yang digunakan adalah 0,789. Kuesioner terdiri dari biodata responden yang identitasnya dirahasiakan serta 20 pernyataan tentang pengetahuan dan pencegahan kanker serviks. Untuk pernyataan positif jika responden menjawab benar dan pernyataan negatif bila menjawab salah. Dalam penelitian ini, analisis yang digunakan yaitu analisis univariat dan bivariat, serta uji statistiknya dalam analisis bivariat dengan uji chi square.

\section{HASIL PENELITIAN}

Tabel. 1

Distribusi Frekuensi Responden Menurut Usia, Pendidikan, Pekerjaan, Paritas, Kejadian Kanker Serviks dan Tingkat Pengetahuan

\begin{tabular}{lcc}
\hline Variabel & Frekuensi & Persentase (\%) \\
\hline Usia & 112 & 77,8 \\
$<20$ tahun & 26 & 18,1 \\
$20-35$ tahun & 6 & 4,2 \\
$>35$ tahun & & \\
\hline Pendidikan & 53 & 36,8 \\
$\quad$ Rendah (SD - SMP) & 91 & 63,2 \\
$\quad$ Tinggi (SMA - PT) & & \\
\hline Pekerjaan & 32 & 22,2 \\
Bekerja & 112 & 77,8 \\
Tidak Bekerja & & \\
\hline Paritas & 61 & 42,4 \\
Primipara & 83 & 57,6 \\
Multipara & & \\
\hline Kejadian Kanker Serviks & 28 & 19,4 \\
Menderita & 116 & 80,6 \\
Tidak Menderita & & 34 \\
\hline Pengetahuan & 49 & 23,6 \\
Baik & 34 & 42,4 \\
Sedang & 61 & \\
Kurang & &
\end{tabular}

Berdasarkan tabel 1 menunjukkan bahwa dari 144 responden, sebagian besar berusia kurang dari 20 tahun yaitu sebanyak 112 responden $(77,8 \%)$, berpendidikan tinggi (SMA - PT) sebanyak 91 responden $(63,2 \%)$, sebagian besar responden tidak bekerja $(77,8 \%)$, kemudian sebanyak $57,6 \%$ responden pernah melahirkan lebih dari 
satu kali (multipara) dan responden yang tidak menderita kanker serviks sebanyak $80,6 \%$ serta sebanyak $42,4 \%$ responden memiliki pengetahuan yang kurang tentang kanker serviks.

Tabel. 2

Hubungan Karakteristik (Usia, Pendidikan, Pekerjaan, Paritas Responden dengan Kejadian Kanker Serviks

\begin{tabular}{|c|c|c|c|c|c|c|c|}
\hline \multirow{3}{*}{ Karakteristik } & \multirow{3}{*}{ Parameter } & \multicolumn{4}{|c|}{ Kejadian Kanker Serviks } & \multirow{3}{*}{ Total } & \multirow{3}{*}{$P$-Value } \\
\hline & & \multicolumn{2}{|c|}{ Menderita } & \multicolumn{2}{|c|}{$\begin{array}{c}\text { Tidak } \\
\text { Menderita }\end{array}$} & & \\
\hline & & $\mathrm{f}$ & $\%$ & $\mathrm{f}$ & $\%$ & & \\
\hline \multirow[t]{3}{*}{ Usia } & $<20$ tahun & 22 & 78,6 & 90 & 80,4 & 112 & \multirow{3}{*}{0,099} \\
\hline & 20-30 tahun & 3 & 11,5 & 23 & 88,5 & 26 & \\
\hline & $>35$ tahun & 3 & 50 & 3 & 50 & 6 & \\
\hline \multirow[t]{2}{*}{ Pendidikan } & Rendah (SD-SMP) & 17 & 32,1 & 36 & 67,9 & 53 & \multirow{2}{*}{0,003} \\
\hline & Tinggi (SMA-PT) & 11 & 12,1 & 80 & 87,9 & 91 & \\
\hline \multirow[t]{2}{*}{ Pekerjaan } & Bekerja & 3 & 9,4 & 29 & 90,6 & 32 & \multirow{2}{*}{0,030} \\
\hline & Tidak Bekerja & 25 & 22,3 & 87 & 77,7 & 112 & \\
\hline \multirow[t]{2}{*}{ Paritas } & Primipara & 6 & 9,8 & 55 & 90,2 & 61 & \multirow{2}{*}{0,013} \\
\hline & Multipara & 22 & 26,5 & 61 & 73,5 & 83 & \\
\hline
\end{tabular}

Berdasarkan tabel 2 menunjukkan bahwa analisa bivariat antara karakteristik responden dengan kejadian kanker serviks. Sebagian besar responden yang berusia kurang dari 20 tahun $(78,6 \%)$ menderita kanker serviks. Hasil uji statistik didapatkan $p$ value 0,099 >0.05 yang berarti tidak ada hubungan bermakna antara usia dengan kejadian kanker serviks di RS "X". Untuk karakteristik pendidikan, responden yang pendidikan rendah (SD-SMP) dan menderita kanker serviks sebanyak 32,1\% dan sisanya $(67,9 \%)$ tidak menderita kanker serviks. Uji bivariat didapatkan nilai $p$-value $0.003<0.05$ yang berarti ada hubungan bermakna antara pendidikan dengan kejadian kanker serviks di RS "X”.

Pada variabel pekerjaan, terlihat bahwa responden yang tidak bekerja dan menderita kanker serviks sebanyak 22,3\% dan 77,7\% tidak menderita kanker seviks serta tampak ada hubungan bermakna antara pekerjaan dengan kejadian kanker serviks dengan $p$-value $0,030<0,05$. Pada variabel paritas, responden dengasn multipara dan menderita kanker serviks sebesar $26,5 \%$ serta pada analisis bivariat tampak adanya hubungan antara paritas dengan kejadian kanker serviks ( $p$ value $0.013<0,05$ ).

Tabel. 3

Hubungan Tingkat Pengetahuan Responden dengan Kejadian Kanker Serviks

\begin{tabular}{|c|c|c|c|c|c|c|c|}
\hline \multirow{3}{*}{ Pengetahuan } & \multicolumn{4}{|c|}{ Kejadian Kanker Serviks } & \multirow{2}{*}{\multicolumn{2}{|c|}{ Total }} & \multirow{3}{*}{ P-Value } \\
\hline & \multicolumn{2}{|c|}{$\begin{array}{c}\text { Menderita } \\
\text { Kanker Serviks }\end{array}$} & \multicolumn{2}{|c|}{$\begin{array}{l}\text { Tidak Menderita } \\
\text { Kanker Serviks }\end{array}$} & & & \\
\hline & $\mathrm{F}$ & $\%$ & $\mathrm{~F}$ & $\%$ & $\mathrm{~F}$ & $\%$ & \\
\hline Baik & 4 & $8,2 \%$ & 45 & $91,8 \%$ & 49 & $100 \%$ & \multirow{4}{*}{0.007} \\
\hline Sedang & 5 & $14,7 \%$ & 29 & $86,3 \%$ & 34 & $100 \%$ & \\
\hline Kurang & 19 & $31,1 \%$ & 42 & $68,9 \%$ & 61 & $100 \%$ & \\
\hline Total & 28 & $19,4 \%$ & 116 & $80,6 \%$ & 144 & $100 \%$ & \\
\hline
\end{tabular}


Berdasarkan tabel 3 memperlihatkan responden yang menderita kanker serviks sebanyak 19,4\% dengan tingkat pengetahuan kurang sebanyak $31,1 \%$. Hasil analisa uji bivariat memperlihatkan adanya hubungan antara tingkat pengetahuan dengan angka kejadian kanker serviks dengan $p$-value 0,007 <0,05.

\section{PEMBAHASAN}

Tabel 1 memperlihatkan responden yang berusia kurang dari 20 tahun dan menderita kanker serviks sebanyak 19,64\% sedangkan sisanya sebanyak 80,36\% tidak menderita kanker serviks. Hasil uji statistik chi-square didapatkan p-value 0,099 (p> 0,05 ) yang berarti tidak ada hubungan bermakna antara usia dengan kejadian kanker serviks. Hasil ini tidak sejalan dengan penelitian yang dilakukan oleh Puspitasari et al., (2018) mengatakan ada hubungan yang signifikan antara usia dengan kejadian kanker serviks ( $p$-value $0,021>0,05$ ). Pola hidup dan budaya hidup sehat yang diterapkan dalam keluarga untuk berperilaku sehat menjadi salah satu faktor yang dapat berpengaruh dalam melakukan pencegahan kanker serviks. Selain itu, pengaruh perkembangan teknologi informasi akan menambah pemahaman seseorang untuk berperilaku hidup sehat.

Tingkat pendidikan seseorang akan membentuk pribadi yang lebih kritis dalam menghadapi berbagai masalah. Semakin tinggi pendidikan maka semakin luas wawasan sehingga mampu berperilaku positif terutama perawatan kesehatan yang ada kaitannya dengan kebersihan alat kelaminnya untuk mengurangi risiko terkena kanker serviks. Penelitian ini memperlihatkan responden dengan pendidikan tinggi (SMA-PT) dan menderita kanker serviks sebanyak 12,1\%, sedangkan yang tidak menderita kanker serviks sebanyak 87,9\%. Hasil uji statistik chi-square didapatkan p-value 0,003 <0,05, memperlihatkan ada hubungan yang signifikan antara pendidikan dengan kejadian kanker serviks. Penelitian ini sejalan dengan penelitian oleh Asyifa (2019) berpendapat ada hubungan pendidikan dengan kejadian kanker serviks dengan p-value 0,029 ( $p<$ $0.05)$.

Responden yang tidak bekerja menderita kanker serviks $22,3 \%$ sedangkan yang tidak menderita kanker serviks sebanyak $77,7 \%$. Uji statistik chi square menghasilkan p-value 0,030 $(<0,05)$ artinya ada hubungan antara pekerjaan dengan kejadian kanker serviks. Penelitian ini tidak sejalan dengan penelitian yang dilakukan oleh Nurlelawati et al., (2018) yang berpendapat tidak ada hubungan bermakna antara pekerjaan dengan kejadian kanker serviks ( $p$ - value $0.303>0.05$ ). Seseorang yang tidak bekerja memiliki banyak waktu luang untuk mendapatkan informasi melalui media komunikasi seperti televisi maupun internet, sehingga dengan banyaknya informasi yang diterima akan mempengaruhi sikap yang lebih positif.

Responden multipara sebanyak 26,5\% menderita kanker serviks, sedangkan tidak menderita kanker serviks sebanyak $73,5 \%$. Hasil uji chi square dengan paritas didapatkan $p$-value $0,013(<0,05)$ berarti ada hubungan antara paritas dengan kejadian kanker serviks. Penelitian ini sejalan dengan penelitian (Salwa et al., 2019) yang menyatakan bahwa ada hubungan antara paritas dengan kejadian kanker serviks. Penelitian ini bertentangan dengan pendapat Wanda et al., (2018) yang mengatakan tidak ada hubungan bermakna antara paritas dengan kejadian kanker serviks ( $p$-value $0,246>0,005)$. Paritas dapat menjadi salah satu faktor awal terjadinya perubahan sel abnormal serviks karena pada saat melahirkan imunitas tubuh pada ibu mengalami penurunan dan terjadi trauma pada serviks. 
Sejalan dengan penelitian yang dilakukan Husnah \& Kurniati yang menyatakan bahwa Hasil uji statistik Chi-Square dengan nilai p-value antara paritas dengan kanker serviks adalah 0,011 ( $\mathrm{p}$-value $<0,05$ ), yang artinya terdapat hubunga paritas dengan kejadian kanker serviks di RSU PKU Muhammadiyah Bantul Yogyakarta.

Pendapat berbeda dikatakan oleh Asyifa (2019) dalam penelitiannya yang menyatakan bahwa paritas tidak memiliki hubungan dengan kanker serviks karena masih ada hal lain yang kemungkinan berpengaruh terhadap terjadinya kanker serviks pada seorang wanita, yaitu pemakaian kontrasepsi. Wanita yang melahirkan sering dengan jarak yang terlalu dekat, berisiko menimbulkan kerusakan pada jaringan epitel dan berkembang ke arah pertumbuhan sel abnormal yang berpotensi ganas.

Kejadian kanker serviks juga berkaitan dengan pengetahuan dan pada table 3 diperlihatkan bahwa 31,1\% responden yang memiliki pengetahuan kurang menderita kanker serviks dan sisanya sebanyak $68,9 \%$ tidak menderita kanker serviks. Hasil uji chi-square menunjukkan $p$-value $0.007<0.05$ yang berarti ada hubungan bermakna antara pengetahuan dengan kejadian kanker serviks. Penelitian ini sejalan dengan penelitian yang dilakukan oleh Nurlelawati et al., (2018) yang mengatakan ada hubungan antara pengetahuan dengan kejadian kanker serviks. Hasil penelitian menunjukkan $p$-value $0.046<0.05$. Dari hasil penelitian ini, terlihat bahwa ada hubungan yang bermakna antara pengetahuan dengan kejadian kanker serviks. Dari enam tingkat pengetahuan peneliti menilai bahwa responden yang diteliti tingkat pengetahuan yang dimiliki oleh responden baru sampai ke tingkat dua yaitu memahami. Hal ini dilihat dari hasil jawaban kuesioner penelitian.

Banyak faktor yang mempengaruhi seorang wanita terkena kanker serviks, diantaranya usia aktivitas seksual pertama kali, usia saat ini, pendidikan serta gaya hidup (Puspitasari et al., 2018; Nurlelawati et al., 2018). Pada beberapa penelitian kasus ini tidak memiliki hubungan yang signifikan dengan pekerjaan serta paritas ibu (Nurlelawati et al., 2018; Puspitasari et al., 2018; Wasiah, 2019).

Penelitian yang dilakukan oleh Kusmiyati., et al (2019) juga mengatakan bahwa lamanya durasi pemakaian alat kontrasepsi hormonal pada akseptor KB memiliki pengaruh terhadap angka kejadian kanker serviks. Kejadian kanker serviks akan meningkat empat kali lebih besar pada akseptor KB yang menggunakan alat kontrasepsi hormonal dengan durasi waktu lebih dari lima tahun dibandingkan akseptor yang menggunakan alat kontrasepsi hormonal dengan lama waktu penggunaan kurang dari lima tahun.

\section{SIMPULAN}

Ada hubungan bermakna antara pendidikan, pekerjaan, paritas dan pengetahuan responden dengan kejadian kanker serviks. Sedangkan usia responden tidak memiliki hubungan bermakna dengan kejadian kanker serviks.

\section{SARAN}

Bagi pelayanan keperawatan dan institusi kesehatan, diharapkan hasil penelitian ini dapat digunakan sebagai masukan bagi tenaga kesehatan, dalam memberikan informasi dan edukasi di unit rawat jalan poli ginekologi kebidanan dan wilayah binaan tentang pengetahuan kanker serviks.

Bagi institusi pendidikan kesehatan, hasil yang didapat dari penelitian ini diharapkan bisa berguna untuk memberi masukkan dalam bahan ajar sebagai angka evidence base sehingga ada peningkatan kemampuan peserta didik terutama dalam 
memberikan penyuluhan tentang pencegahan dan deteksi dini kanker serviks bagi masyarakat.

Rekomendasi yang dapat diberikan untuk penelitian lebih lanjut adalah diharapkan dapat melihat variabel lain yang lebih bervariasi yang terkait dengan kejadian kanker serviks.

\section{DAFTAR PUSTAKA}

Asyifa, F. (2019). Hubungan antara Paritas dan Tingkat Pendidikan terhadap Kejadian Kanker Serviks. 1-15. http://eprints.ums.ac.id/69718/23/NASKAH PUBLIKASIfannniiii.pdf

Herlana, F., Nur, I. M., \& Purbaningsih, W. (2017). Karakteristik Pasien Kanker Serviks berdasar atas Usia, Paritas, dan Gambaran Histopatologi di RSUD Al-Ihsan Bandung. Bandung Meeting on Global Medicine \& Health (BAMGMH), 1(1), 138-142. http://proceeding.unisba.ac.id/index.php/BaMGMH/article/view/1481

Husnah, A., \& Kurniati, N. (2018). Hubungan Paritas dan Umur dengan Kejadian Kanker Serviks di RS PKU Muhammadiyah Bantul Yogyakarta. Universitas 'Aisyiyah Yogyakarta. http://digilib.unisayogya.ac.id/4149/1/NASKAH\%20PUBLIKASI.pdf

Kemkes RI, 2019. (2019). Deteksi dini cegah kanker. 1-2

Kusmiyati, Y., Prasistyami, A., Wahyuningsih, H. P., Widyasih, H., \& Adnani, Q. E. S. (2019). Duration of Hormonal Contraception and Risk of Cervical Cancer. Kesmas, 14(1), 9-13. https://doi.org/10.21109/kesmas.v14i1.2713

Nurlelawati, E., Devi, T. E. R., \& Sumiati, I. (2018). Faktor yang Berhubungan dengan Kejadian Kanker Serviks di RS Pusat Pertamina Jakarta. Midwife Journal, 5(01), 8-16. https://media.neliti.com/media/publications/234022-faktor-faktor-yangberhubungan-dengan-ke-4c9aa2a2.pdf

Puspitasari, N., Endah, S., \& Setiowati, T. (2018). Hubungan Usia, Paritas dan Usia Aktivitas Seksual Pertama Kali dengan Kejadian Kanker Serviks di Ruang Rawat Inap (Alamanda \& Kemuning) RSUP dr. Hasan Sadikin Bandung Provinsi Jawa Barat. Jurnal Kesehatan Kartika, 11(3), 47-59. https://123dok.com/document/y62k12nz

Salwa, S., Sari, Y., \& Taufik, A. (2019). Faktor-Faktor yang Berhubungan dengan Kejadian Kanker Serviks di Rsud Prof. Dr. Margono Soekarjo Purwokerto Universitas Jenderal Soedirman]. https://doi.org/10.15036/arerugi.44.821_2

Surbakti, E. (2020). Determinan Deteksi Dini Kanker Serviks pada Wanita Usia Subur. Jurnal Ilmiah PANNMED (Pharmacist, Analyst, Nurse, Nutrition, Midwivery, Environment, Dentist), 15(2), 153-160. https://doi.org/10.36911/pannmed.v15i2.671

Trifitriana, M., Sanif, R., Husin, S., \& Mulawarman, R. (2020). Risk Factors of Cervical Cancer in Outpatient and Inpatient at Obstetric and Gynecology RSUP Dr. Mohammad Hoesin Palembang. Medicinus, 7(5), 133. https://doi.org/10.19166/med.v7i5.2470

Wanda, M., Oktavia, N. S., \& Yusefni, E. (2018). Faktor-Faktor yang Berhubungan dengan Kejadian Kanker Serviks di Ruangan Ginekologi RSUP M.Djamil Padang Tahun 2017. JIK- Jurnal Ilmu Kesehatan, 2(1), 79-85. https://doi.org/10.33757/jik.v2i1.82 
Wasiah, A. (2019). Hubungan Paritas terhadap Kejadian Kanker Serviks di RSUD Dr. Soegiri Kabupaten Lamongan. Jurnal Midpro, 11(2), 128-133. https://doi.org/10.30736/md.v11i2.121

WHO. (2019). Cervical Cancer. https://www.who.int/news-room/factsheets/detail/human-papillomavirus-(hpv)-and-cervical-cancer 